\title{
Institutions and the losses from natural disasters
}

\author{
P. A. Raschky \\ Institute of Public Finance, University of Innsbruck, Universitaetsstrasse 15, A-6020 Innsbruck and alpS - Center for Natural \\ Hazard Management, Innsbruck, Austria
}

Received: 9 October 2007 - Revised: 17 March 2008 - Accepted: 19 May 2008 - Published: 1 July 2008

\begin{abstract}
Natural hazards can be seen as a function of a specific natural process and human (economic) activity. Whereby the bulk of literature on natural hazard management has its focus on the natural process, an increasing number of scholars is emphasizing the importance of human activity in this context. Existing literature has identified certain socioeconomic factors that determine the impact of natural disasters on society. The purpose of this paper is to highlight the effects of the institutional framework that influences human behavior by setting incentives and to point out the importance of institutional vulnerability. Results from an empirical investigation of large scale natural disasters between 1984 and 2004 show that countries with better institutions experience less victims and lower economic losses from natural disasters. In addition, the results suggest a non-linear relationship between economic development and economic disaster losses. The suggestions in this paper have implications for the discussion on how to deal with the adverse effects of natural hazards and how to develop efficient adaption strategies.
\end{abstract}

\section{Introduction}

The absolute number of natural catastrophes within the last ten years as compared to the 1960s has increased by a factor of 2.2 the economic losses from natural hazards have been increasing by a factor of 6.7 in the same period (Munich Re Group, 2004). In addition, the recent report from the Intergovernmental Panel on Climate Change (IPCC) suggests that economic losses from natural hazards are world-wide on the rise and this trend is not going to stop in the near future (Parry et al., 2007). People settle down in regions exposed to natural

\section{Correspondence to: P. A. Raschky}

(paul.raschky@uibk.ac.at) hazards that have been untouched before and the population density in hazardous areas is constantly increasing. This development has got several reasons:

(a) The exploitation of scarce resources in these areas for production purposes. These could either be natural resources such as fossil fuels, metals, minerals or agricultural resources as well as landscapes for tourism or health purposes.

(b) Population is growing, and space to settle down is limited. Hence, urban areas are expanding and people move to new areas.

(c) People try to escape from over-populated urban areas in order to increase their living standards.

So far, natural disasters are viewed as sudden shocks to society and the economy. However, several scientific sources ${ }^{1}$ suggest that anthropogenic climate change increases the frequency of extreme weather events and change the climate in certain regions tremendously. This increase in frequency of events could mean that at least in some regions of the world natural catastrophes may become "normality" rather than rare shocks. Therefore, it is essential to identify the factors that determine a society's vulnerability against natural hazards (Fuchs et al., 2007). Apart from country-specific climatic and topographic factors numerous socio-economic factors have been found to be key determinants of a society's response to natural hazards. The level of economic development both determines the groups within society most affected by disasters (Albala-Bertrand, 1993) and the probability of survival (Kahn, 2005). Skidmore and Toya (2007) found that higher income, educational attainment and greater openness

\footnotetext{
${ }^{1}$ See Parry et al. (2007) or Steininger and Weck-Hannemann (2002) for Alpine regions.
}

Published by Copernicus Publications on behalf of the European Geosciences Union. 
for trade reduces both capital losses and human fatalities. Using data on major earthquakes Anbarci et al. (2005) show that countries with higher income inequality (measured by the Gini-coefficient ${ }^{2}$ ) experience higher fatality rates.

The purpose of this paper is to augment this existing field of natural hazard research by the factor of institutional vulnerability. The basic question underlying this analysis is: "How do natural hazards affect society?" If a river runs over the bank or an avalanche runs down a hill it is not a natural disaster per se it is just a natural process. The natural process becomes a "natural hazard" as soon as human beings, infrastructure or other forms of tangible or intangible capital is threatened and/or destroyed (Varnes, 1988). Whether this natural process does not affect individuals at all or "evolves" to a natural disaster is not solely in the realm of the natural environmental, but crucially depends on the behavior of human beings living in this environment. Based on the ideas of institutional economics, human (economic) activity is determined by institutions. In this case (and throughout this paper) institutions do not solely describe formal organisations but rather encompass general rules of human interaction and political decision-making, laws and policies as well as traditions or norms. This institutional framework sets the incentives that affect individuals' actions and conversely institutions evolve from human activity (Frey, 1990). Some institutional settings result in economic growth and development, while other institutions results in stagnation (Acemoglu et al., 2001). Countries with better institutions and less distortionary policies invest more in physical and human capital and apply their existing factor endowment more efficiently (North, 1990). This could also apply to a nation's effort to mitigate the effects of natural hazards. Therefore, an analysis of the effects of natural hazards on society does not solely depend on a region's topographic or climatic exposure to natural processes orits level of economic development but the region's institutional vulnerability to natural processes that ultimately determines whether natural processes result in a natural hazard or not.

The purpose of this paper is twofold: first, the relationship between economic development and vulnerability against natural disasters is examined. The results suggest that economic development partly reduces disaster victims and losses, but increasing wealth inverts this relationship and thus causes relatively higher (economic) losses in highincome nations. Based on these results the study wants to point out that higher income does not necessarily lead to better protection against natural disasters. Therefore, the second aim is to highlight the importance of institutional quality as an additional socio-economic factor to provide protection against natural hazards. Although some studies have already touched the interaction between institutional quality and the

\footnotetext{
${ }^{2}$ The Gini coefficient is a statistical measure of income inequality. It ranges from 0 (income is equally distributed among the members of society) to 1 (perfect inequality).
}

death toll from earthquakes (Kahn, 2005) or output volatility caused by natural hazards (Raddatz, 2005) a comparative empirical analysis of institutional quality on economic disaster losses is missing. The econometric study in this paper tries to fill this gap.

The next section gives an overview of the existing literature. Section 3 discusses the relevance of institutional vulnerability in natural hazard management. Section 4 provides an empirical analysis of this issue and section 5 concludes.

\section{Socio-economic determinants of disaster losses}

The direct effect of a disaster on society is the loss of human lives and the destruction of physical capital. Direct destruction of input factors is followed by disruptions in production and output. The cross-country analysis by Tavares (2004) shows that natural disasters have a small but negative effect on economic growth. Several studies concentrating on the macro-economic impacts of natural disasters on developing countries provide similar results. Rasmussen (2004) presents a comprehensive study of natural disasters in the Eastern Caribbean Currency Union. He concludes that disaster damages in this area amount to about $0.5 \%$ of GDP. The panel study by Auffret (2003) also finds a decline in output due to natural disasters in Latin American and Caribbean economies.

Empirical economic analysis on vulnerability has identified a number of factors that mitigate the impacts of natural catastrophes on society. There is broad consensus that economic development mitigates the effects from natural disasters. Kahn (2005) shows that countries with higher per capita income experience a similar amount of catastrophic events but suffer less death from these events. Using a sample of 3893 major catastrophes Skidmore and Toya (2007) confirm this finding. They also find that economic development and economic losses from disasters are inversely correlated. In addition, Skidmore and Toya (2007) identify a number of other factors of social exposure: Nation with higher levels of educational attainment and greater openness for trade are less vulnerable to disasters. A stronger financial sector and a smaller size of government (measured as the fraction of government expenditure per GDP) are associated with a lower disaster death toll. Anbarci et al. (2005) analyse the effects income inequality (using the Gini coefficient) on earthquake fatalities. Their results suggest that a nation's inequality as a proxy for the nation's inability to adopt preventive measures and policies (e.g. the creation and enforcement of building codes) - increases the number of earthquake fatalities. 


\section{Institutional vulnerability}

Institutions define and constrain the set of choices of individuals. If this applies to economic activities in general North (1990), this should also apply to decisions related to protection against natural hazards. Decisions linked to protection measures and natural hazard mitigation strategies take place in a complex environment. A vast amount of different economic, social and environmental variables need to be taken into account during the decision making process which creates uncertainty for the individual. It is the purpose of institutions to reduce this individual uncertainty. According to North (1990) "Institutions are the rules of the game in a society or, more formally, are the humanly devised constraints that shape human interaction" (p. 3). This rather general definition of institutions was more specified by Frey (1990), who classifies three types of institutions:

1. Institutions are rules or procedures that clarify how decisions are made within society. These decision-making systems can be the market, democracy, hierarchical decision-making or negotiating systems. In the area of natural hazard management the market and possible imperfections and distortions as well as drawbacks of the existing political mechanisms are of particular importance.

2. Formal or informal rules that influence individual behavior such as laws, social norms, traditions or informal rules defining the behavior within a group or the family. Regarding natural hazards this type of institutions could range from the general legal setting (regulating i.e. preventive measures, financial support in the case of emergency, the distribution of competencies) to the behavioral standards within a ski-hiking group in an avalanche prone area.

3. Groups of individuals that share a common aim - organizations. These could be e.g. political parties, authorities, companies, NGOs or clubs.

Beside politicians, companies or interest groups, organizations such as insurance companies, experts or tourist associations might be of special interests in the area of natural hazards. The aim is to find which institutional setting builds the frame under which individual preferences for natural hazard management and protective measures are reflected in an optimal way (Weck-Hannemann, 2005). Prior to the decision, which institutional framework is to choose for the allocation of resources in natural hazard management, a comparison between the existing alternatives is required. However, a precise calculation of an institutional system's inefficiencies is not possible. At least a positive comparison of alternative institutional designs in natural hazard management allows to examine the strengths and weaknesses of different systems and identify more efficient institutions. Thus far, only a few empirical studies analysed the effects of instituions on vulnerability against natural hazards. The empirical work by Kahn (2005) shows that better institutional quality insulates against death from earthquakes. He used a nation's level of democracy, income inequality, ethnic fragmentation and good governance indicators as proxies for institutional quality. Countries with better institutions, lower income inequality and higher levels of democracy experience fewer earthquake fatalities. He argues that this might be explained that nations with a bad instituional framework do not properly enforce zoning laws and building codes. Apart from these general institutional variables substantial work has been done regarding the societal risk-transfer-mechanisms (e.g. disaster insurance, governmental relief) to reduce the financial losses from disasters. The market for insurance against flooding works imperfectly or fails completely. Adverse selection and moral hazard can only partly explain these market imperfections (Jaffee and Russell, 2003). Kunreuther (2000) defined the situation of distorted demand and insufficient supply on the market for natural hazard insurance as the disaster syndrome. Individuals tend to underinsure because of a) the underestimation of risk of low-probability high loss events and b) the expected financial relief by the government or private charity. This market failure has led to different forms of government intervention in the market for disaster insurance. In Europe several countries (France, Great Britain, Spain and Switzerland) have installed a system of mandatory insurance, where every house-owner and company is obliged to purchase insurance coverage against natural-disaster-risks (for an overview of the different forms in each country see Von Ungern-Sternberg, 2004).

In regions without institutionalized insurance regimes, risk-transfer against natural hazards is in the realm of the individuals and politicians. According to Skidmore (2001) individuals try to protect themselves against potential disaster damages by building up a capital buffer. His results suggest that this form of self-protecting is rather inefficient as the buffer stock is very often larger than the actual losses. However, if self-insurance does not cover the disaster losses governments provide catastrophe assistance and financial relief. Governmental relief is either organized through a fund (e.g. Austria) or politicians provide ad-hoc financial assistance to the victims (e.g. Germany).

Governmental disaster assistance can lead to the problem of charity hazard, the phenomenon that people underinsure or do not insure at all due to anticipated governmental assistance and/or private charity (Raschky and Weck-Hannemann, 2007; Schwarze and Wagner, 2004). In addition to an inefficient amount of insurance coverage, financial assistance from the government does rarely meet the needs of the disaster victims and leads to an inefficient allocation of public funds. An econometric study by Garrett and Sobel (2003) show that almost half of federal disaster payments in the US are politically motivated. They show that disaster expenditure by the FEMA (Federal Emergency Management Agency) is 
significantly higher in election years (around \$ 140 million as compared to non-election years) and that states with higher political impact have on average a higher rate of disaster declarations (a requisite for financial assistance). Besley and Burgess (2002) find similar results using panel date from India on governmental food programs after flooding destroyed crop. The work by Mustafa (2003) concluded that after the 2001 in Pakistan public support cheques where mainly distributed among family members and political supporters of local councilors coordinating the governmental assistance.

The impact of institutions on a more efficient allocation of resources in natural hazard management is not only restricted to post-disaster relief. The identification and mapping of hazard zones, the construction of preventive measures (e.g. dykes, levees or avalanche barriers) or the maintenance of early warning systems largely show the features of public goods (Congleton, 2006). Pure public goods show nonrivalness and non-excludability in consumption. Although the majority of preventive measures are not purely non-rival and non-excludable goods, the concept of public goods is a good explanation why common action is needed in this field. In addition, preventive measures can create positive and negative externalities. Take for example a levee build by an upstream town. Although this town is protected against floods, the levees might result in more water in the river channel and thus increasing the risk of a flood for downstream communities. This is another reason why most of the above mentioned pre-disaster measures are provided by federal governments and agencies or international organizations.

If the responsibility for public good projects in natural hazard management is highly centralized, a informational deficit occurs between the central agency and the local demands. These differences can lead to an inefficient allocation of public funds and an inappropriate provision of protective measures. Case studies on the events linked to hurricane "Katrina" by Congleton (2006) and Sobel and Leeson (2006) show how centralized action leads to an insufficient supply of preventive measures against floods in New Orleans and delayed governmental response in the aftermath. Pelling (1999) argues that a political system where decision-making power is in the hands of an elite increases the vulnerability against floods of specific population groups in Guyana. Depoorter (2006) suggests that shared political accountability is an additional reason for deficits in disaster management.

Political economists also identify constitutions that protect individual property rights as a key for allocative efficiency and economic development. Human economic interaction can be subject to informational asymmetries, free-riding and incentives to shirk. Uncertainty and lack of information in the exchange of goods that are accompanied with natural hazards (e.g. housing) lead exactly to these inefficiencies. A constitutional environment that enforces property rights can decrease transaction costs, reduce uncertainty and provide individuals with some degree of security (Leblang, 1996). A legal system that fosters transperancy and disclosure of haz- ards increases the level of information for all participants in a transaction and could lead to more risk-aware decisions of individuals within society. Using data of the California housing market, Beron et al. (1997) show the positive effects of a law that enforces the disclosure of earthquake risks during real estate transactions. After the information disclosure act was issued house prices reflected the earthquake risk of a property in a better way.

\section{Empirical analysis}

In this section an empirical analysis on the effects of institutions on disaster losses is presented. Data on natural disasters stem from the EM-DAT Center for Research on the Epidemiology of Disasters (CRED) in Brussels (EM-DAT, 2007). EM-DAT has collected around 12000 reports of different disasters, such as flood, storms, earthquakes, volcanic eruptions, landslides or tsunamis. The disaster has to fulfill at least one of the following criteria in order to be included in the database: 10 or more people reported killed, 100 people reported affected, declaration of a state of emergency, call for international assistance. Therefore, disasters that occurred in thinly populated areas are not included in the database and in the analysis. This dataset provides information about the location of the disaster, the total number of people killed and affected as well as the total losses (in 1000 USD). The sample includes data on earthquakes, floods, wind storms, volcanic eruptions, tidal waves, landslides, avalanches, droughts, extreme temperature events and wild fires. Data on economic development, measured by per capita gross domestic product (GDP p.c.), and population are provided by the Penn World Table 6.2 Heston, Alan and Summers, Robert and Aten, Bettina (2006). The International Country Risk Guide ${ }^{3}$ provided the data on institutional aspects (The PRS Group Inc., 2006). In order to limit the scope of this empirical analysis the examination is limited to two specific institutional indicators that reflect a wide area of a nation's institutional framework. The first one is governmental stability, which is an assessment of both, the national government's ability to carry out its declared program(s) and its ability to stay in office. It consists of three components: governmental unity, legislative strength and popular support. This indicator serves as a proxy for a country's ability to issue laws and regulations as well as enforce existing laws. A higher level of this institutional variable should indicate the existence of more efficient preventive policies and a stronger enforcement of these policies (e.g. zoning and building codes). The second institutional indicator is investment climate. This indicator covers institutional rules such as the risk of expropriation or contract law. The main intention to include this indicator stems

\footnotetext{
${ }^{3}$ The International Country Risk Guide is a collection of political information and economic data. The assessment of political risks is based on the subjective assignment of specific risk-points to each category by experts of the PRS Group.
} 
Table 1. Descriptive statistics.

\begin{tabular}{llllll}
\hline Variable & Obs. & Mean & Std. Dev. & Min. & Max. \\
\hline $\begin{array}{l}\text { Total no. killed } \\
\text { (per 1.000 inh.) }\end{array}$ & 2.903 & 0.009 & 0.007 & $7.77 \mathrm{E}^{-7}$ & 2.474 \\
$\begin{array}{l}\text { Damage/GDP } \\
\text { GDP p.c. }\end{array}$ & 1103 & 0.152 & 0.217 & $1.98 \mathrm{E}^{-6}$ & 0.997 \\
$\begin{array}{l}\text { Total affected } \\
\begin{array}{l}\text { Government } \\
\text { stabillity }\end{array}\end{array}$ & 2.903 & 1083408 & 1040000 & 0 & 3900000000 \\
$\begin{array}{l}\text { Investment } \\
\text { climate }\end{array}$ & 2.903 & 7.887 & 2.354 & 1 & 12 \\
\hline
\end{tabular}

from the idea that property rights are a key determinant for an efficient allocation of resources, which is also important in natural hazard management. The sample size is restricted mainly by the availability of data on disaster losses and the collected institutional indicators. The International Country Risk Guide starts at 1984. Therefore the disasters in this sample took place between 1984 and 2004. Data on the death toll and economic disaster losses ${ }^{4}$ are not available for all disasters in the EM-DAT. The final sample consists of 2792 events where numbers of disaster victims are available and 1103 events with figures on economic losses. Table 1 reports the descriptive statistics of the disaster losses as well as the key socio-economic variables ${ }^{5}$.

To determine the relationship between economic development, institutional vulnerability and disaster impacts, the following log-log regression function ${ }^{6}$ is derived:

$$
\begin{aligned}
& \operatorname{Ln}\left(\operatorname{Losses}_{i j t}\right)=\beta_{0}+\beta_{1} \operatorname{Ln}\left(\mathrm{GDP}_{j t}\right)+\beta_{2} \operatorname{Ln}\left(\mathrm{GDP}_{j t}^{2}\right) \\
& +\beta_{3} \operatorname{Ln}\left(\text { Affected }_{i j t}\right)+\beta_{4} \operatorname{Ln}\left(\operatorname{Land~area}_{j t}\right) \\
& +\beta_{5} \operatorname{Ln}\left(\text { Population }_{j t}\right)+\beta_{6} \mathrm{INST}_{j t}+\epsilon_{i j t}
\end{aligned}
$$

where $\mathrm{LN}\left(\operatorname{Losses}_{i j t}\right)$ reflects the dependent variables in the two sets of regressions that are estimated. The first analysis focuses on disaster fatalities, $\mathrm{LN}\left(\right.$ Deaths $\left._{i j t}\right)$, of disaster event $i$, in country $j$ and year $t$. In order to test the assumption that the relationship between losses and level of development

\footnotetext{
${ }^{4}$ Kahn (2005) and Skidmore and Toya (2007) already argued that the numbers on economic losses should be interpreted with care. In particular, developing countries have an incentive to exaggerate damage costs to receive higher international disaster assistance. In addition, damage data from developing countries is very often inaccurate due to the lack of insurance markets, bookkeeping and governmental bureaus collecting data in an appropriate way.

${ }^{5}$ The large max. value of total affected of 300000000 stems from the 1987 drought in India

${ }^{6}$ Taking the natural $\log$ of the variables allows to interpret the regression coefficient as elasticities. This makes the different coefficients more comparable. For the institutional variables no logarithmic transformation was applied.
}

is non-linear the natural $\log$ of GDP p.c., $\mathrm{LN}\left(\mathrm{GDP}_{j t}\right)$, and , $\mathrm{LN}\left(\mathrm{GDP}_{j t}\right)^{2}$, are introduced simultaneously. To control for the social magnitude of a disaster the natural log the total number of affected people, LN(Affected ${ }_{i j t}$ ), is taken. In accordance with Skidmore and Toya (2007) land area, Land $\operatorname{area}_{j t}$, and population, Population ${ }_{j t}$, are included as additional control variables. The variable of main interest is represented by vector $\mathrm{INST}_{j t}$, that includes the indicator for governmental stability and investment climate. $\beta_{x}$ are coefficients to be estimated and $\epsilon_{i j t}$ is the error term. In the second set of estimates, $\mathrm{LN}\left(\right.$ Deaths $\left._{i j t}\right)$ is replaced by the monetary damage caused by event $i$, in country $j$ at time $t, \mathrm{LN}\left(\frac{\text { Damage }}{\text { GDP }}_{i j t}\right)$,

According to the existing empirical literature the level of economic evelopment reduces disaster losses. However, this effect it is reasonable to assume that the mitigative effect is diminished higher concentration of wealth that could accompany economic development. Therefore, $\mathrm{LN}\left(\mathrm{GDP}_{j t}\right)$ is expected to have a negative and $\mathrm{LN}\left(\mathrm{GDP}_{j t}\right)^{2}$ a positive sign. Better institutions should lead to a better allocation of resources, better laws and legislation as well as better law and thus decrease the losses. The effect of population and size is ambiguous, although one might expect that bigger countries (in terms of population) have economies of scale in providing mitigative measures and more people increase the damage potential.

The results of both sets of regression are represented in Table 1. Columns 1-3 show the results of the estimates for the determinants of disaster fatalities. The baseline estimates in column 1 indicate that GDP p.c. and population reduce c.p. the number of disaster fatalities, while the social magnitude of the disaster increases the death toll. A $10 \%$ increase in GDP p.c. results in about $8.74 \%$ lower death toll. The results do not support the hypothesis of non-linearity for the estimates on disaster victims. In columns 2 and 3 the institutional variables have been added. Both governmental stability and investment climate significantly reduce the amount of disaster victims signifcantly. A 1-point increase on the 12point government stability (investment climate) scale reduces 
Table 2. Natural disaster losses, economic development and institutions.

\begin{tabular}{|c|c|c|c|c|c|c|}
\hline & \multicolumn{3}{|c|}{ LN(Number killed p.c.) } & \multicolumn{3}{|c|}{ LN(Damage/GDP) } \\
\hline & 1 & 2 & 3 & 4 & 5 & 6 \\
\hline Ln(GDP p.c.) & $\begin{array}{l}-0.874^{*} \\
(0.514)\end{array}$ & $\begin{array}{r}-0.841^{*} \\
(0.491)\end{array}$ & $\begin{array}{r}-1.042^{* *} \\
(0.516)\end{array}$ & $\begin{array}{r}-4.784^{* * *} \\
(1.788)\end{array}$ & $\begin{array}{r}-5.012^{* * *} \\
(1.708)\end{array}$ & $\begin{array}{r}-5.771^{* * *} \\
(1.727)\end{array}$ \\
\hline $\operatorname{Ln}(\text { GDP p.c. })^{2}$ & $\begin{array}{r}0.019 \\
(0.030)\end{array}$ & $\begin{array}{r}0.019 \\
(0.029)\end{array}$ & $\begin{array}{r}0.032 \\
(0.031)\end{array}$ & $\begin{array}{r}0.315^{* * *} \\
(0.104)\end{array}$ & $\begin{array}{r}0.299^{* * *} \\
(0.100)\end{array}$ & $\begin{array}{r}0.348^{* * *} \\
(0.103)\end{array}$ \\
\hline Ln(Number affected) & $\begin{array}{r}0.180^{* * *} \\
(0.014)\end{array}$ & $\begin{array}{r}0.172^{* * * *} \\
(0.014)\end{array}$ & $\begin{array}{r}0.178^{* * * *} \\
(0.014)\end{array}$ & $\begin{array}{r}0.404^{* * *} \\
(0.024)\end{array}$ & $\begin{array}{r}0.403^{* * *} \\
(0.024)\end{array}$ & $\begin{array}{r}0.401^{* * * *} \\
(0.024)\end{array}$ \\
\hline LN(Land area) & $\begin{array}{r}0.001 \\
(0.043)\end{array}$ & $\begin{array}{r}0.008 \\
(0.043)\end{array}$ & $\begin{array}{r}0.002 \\
(0.043)\end{array}$ & $\begin{array}{r}0.078 \\
(0.119)\end{array}$ & $\begin{array}{r}0.089 \\
(0.120)\end{array}$ & $\begin{array}{r}0.058 \\
(0.119))\end{array}$ \\
\hline LN(Population) & $\begin{array}{r}-0.896^{* * *} \\
(0.061)\end{array}$ & $\begin{array}{r}-0.892^{* * *} \\
(0.059)\end{array}$ & $\begin{array}{r}-0.896^{* * *} \\
(0.061)\end{array}$ & $\begin{array}{r}-0.880^{* * *} \\
(0.099)\end{array}$ & $\begin{array}{r}-0.867^{* * *} \\
(0.103)\end{array}$ & $\begin{array}{r}-0.850^{* * *} \\
(0.098)\end{array}$ \\
\hline Government stability & & $\begin{array}{r}-0.049^{* * *} \\
(0.012)\end{array}$ & & & $\begin{array}{r}-0.074^{* *} \\
(0.030)\end{array}$ & \\
\hline Investment climate & & & $\begin{array}{r}-0.044^{* *} \\
(0.017)\end{array}$ & & & $\begin{array}{r}-0.115^{* *} \\
(0.119)\end{array}$ \\
\hline Constant & Yes & Yes & Yes & Yes & Yes & Yes \\
\hline$R^{2}$ & 0.529 & 0.531 & 0.530 & 0.205 & 0.212 & 0.212 \\
\hline Prob $>F$ & 0.000 & 0.000 & 0.000 & 0.000 & 0.000 & 0.000 \\
\hline Obs. & 2792 & 2792 & 2792 & 1103 & 1103 & 1103 \\
\hline
\end{tabular}

Notes: Clustered OLS-estimates. Robust standard errors are given in parenthesis.

$* * *, * *, *$ indicate significance at the 1,5 and $10 \%$.

the death toll by about $4.9 \%$ (4.4\%). Considering the crosssection structure of the analysis, all specifications have a reasonable $R^{2}$ (about 50\%) and it increases after the introduction of the institutional variables.

We now turn our focus on the results for economic loss (columns 4-6). Once again the first step was to estimate a baseline specification without controlling for institutions. In contrast to the estimates on disaster victims, $\operatorname{LN}\left(\mathrm{GDP}_{j t}\right)^{2}$ has a significant positive impact on economic disaster losses. This indicates a non-linear relationship between economic development and economic losses. Economic development provides protection but with a diminishing rate. The institutional variables have once again a significant reducing impact on economic losses and support the idea that institutions matter in natural hazard preparedness.

\section{Conclusion and suggestions for future research}

The contribution of this work is to show that the institutional framework is a key socio-economic determinant of a nation's vulnerability against natural disasters. Governmental stability and a lower risk of expropriation have a clearly significant impact on both, the death toll and the overall economic losses from natural disasters. These results suggest that institutions reduce the adverse effects of natural disasters and that institutional vulnerability is a promising issue for future research.
Apart from institutions, the results confirm the idea that economic development is an important factor in determining a society's vulnerability against natural hazards. The results show, that higher-income countries experience a lower death toll from natural disasters. However, the econometric analysis also shows that monetary disaster losses and economic development have a non-linear relationship. This means, that economic development is a good protection against natural hazards, however with a diminishing rate. In countries or areas (e.g. Florida) that experience a concentration of assets that is larger than the installation of appropriate counter measures the relationship of income an vulnerability could even invert. However, the focus of empirical economic research so far was mainly on the effect of economic development and only to a limited extent on other socio-economic variables.

Future research on institutional vulnerability should incorporate a number of issues. The empirical studies on the effects of natural hazards on economic development have a clear mid to long-run perspective. However, according to the suggestions in the recent IPCC-report the frequency of climate-induced natural disasters (e.g. hurricanes, floods) is likely to increase in the near future (Parry et al., 2007). This calls for more emphasis on the analysis of the shortterm effects of natural disasters on society. The analysis by Albala-Bertrand (1993) and Auffret (2003) estimated the short-term effects of disaster losses on economy. In contrary to the results of long-run estimates (Skidmore and Toya, 2002) e.g. Raschky (2007) found that flood disaster do have 
a negative effect on regional economy in the short-run. Regarding the impact on factor productivity Leiter et al. (2007) find that firms' productivity tends to be reduced in the shortrun despite a higher level of factor input. In order to design more efficient societal decision mechanisms in natural hazard management we have to gain a more comprehensive picture on both short and long run impacts of disasters on economic welfare.

The results presented in this paper only have an explorative character. Future (empirical) research efforts should be directed towards a more detailed analysis of the interaction between institutional constraints and the sustainable provision of protective measures. The understanding of incentive schemes and the identifcation of efficient instituional settings allows the design of more appropriate societal decisionmechanisms in natural hazard management.

Acknowledgement. This paper originated as part of a project at alpS - Center for Natural Hazard Management (Innsbruck, Austria) in cooperation with the Institute of Public Finance, University of Innsbruck (Austria). Financial support by the Hypo Tirol Bank is gratefully acknowledged. The author would like to thank two anonymous referees for their helpful comments and reviews of an earlier version of this paper.

Edited by: S. Fuchs, M. Brndl, R. Bernknopf, and T. Glade Reviewed by: two anonymous referees

\section{References}

Acemoglu, D., Johnson, S., and Robinson, J. A.: The Colonial Origins Of Comparative Development: An Empirical Investigation, American Economic Review, 91, 1369-1401, 2001.

Albala-Bertrand, J. M.: Natural Disaster Situations and Growth: A Macroeconomic Model for Sudden Disaster Impacts, World Development, 21, 1417-1434, 1993.

Anbarci, N., Escaleras, M., and Register, C. A.: Earthquake Fatalities: The Interaction of Nature and Political Economy, Journal of Public Economics, 89, 1907-1933, 2005.

Auffret, P.: High Consumption Volatility: The Impact of Natural Disasters?, World bank policy research paper 2962, World Bank, 2003.

Beron, K. J., Murdoch, J. C., Thayer, M. A., and Vijverberg, W. P. M.: An Analysis of the Housing Market Before and After the 1989 Loma Prieta Earthquake, Land Economics, 73, 101-113, 1997.

Besley, T. and Burgess, R.: The Political Economy of Government Responsiveness: Theory and Evidence from India, The Quarterly Journal of Economics, 117, 1415-1451, 2002.

Congleton, R. D.: The Story of Katrina: New Orleans and the Political Economy of Catastrophe, Public Choice, 127, 5-30, 2006.

Depoorter, B.: Horizontal Political Externalities: The Supply and Demand of Disaster Management, Duke Law Journal, 56, 101$125,2006$.
EM-DAT: International Disaster Database, www.em-dat.net, 2007.

Frey, B. S.: Oekonomie ist Sozialwissenschaft: Die Sicht der Politischen Oekonomie, Staatswissenschaft und Staatspraxis, 2, 158175, 1990.

Fuchs, S., Heiss, K., and Huebl, J.: Towards an Empirical Vulnerability Function for Use in Debris Flow Risk Assessment, Nat. Hazards Earth Syst. Sci., 7, 495-506, 2007, http://www.nat-hazards-earth-syst-sci.net/7/495/2007/.

Garrett, T. A. and Sobel, R. S.: The Political Economy of FEMA Disaster Payments, Economic Inquiry, 41, 496-509, 2003.

Heston, A., Summers, R., and Aten, B.: Penn World Table Version 6.2, Tech. rep., Center for International Comparisons of Production, Income and Prices at the University of Pennsylvania, 2006.

Jaffee, D. and Russell, T.: Markets under stress: The Case of Extreme Event Insurance, in: Economics of an Imperfect World, edited by: Arnott, R., Greenwald, B., Kanbur, R., and Nalebuff, B., 35-52, MIT Press, 2003.

Kahn, M. E.: The Death Toll from Natural Disasters: The Role of Income, Geography and Institutions, The Review of Economics and Statistics, 87, 271-284, 2005.

Kunreuther, H.: Strategies for Dealing with Large-scale and Environmental Risks, in: Frontiers in Environmental Economics, edited by Folmer, H., Gabel, L., Gerking, S., and Rose, A., 293318, Edward Elgar, 2000.

Leblang, D. A.: Property Rights, Democracy and Economic Growth, Political Research Quarterly, 49, 5-26, 1996.

Leiter, A., Oberhofer, H., and Raschky, P. A.: Productive Disasters? Evidence from European Firm Level Data, working Papers in Economics and Statistics No. 2007-25, University of Innsbruck, 2007.

Munich Re Group: Topics Geo: Natural catastrophes 2003: Analyses, Assessments and Positions, Knowledge series, Munich Re, Geo Risks Research, 2004.

Mustafa, D.: Reinforcing Vulnerability? Disaster Relief, Recovery and Response to the 2001 Flood in Rawalpindi, Pakistan, Environmental Hazards, 5, 71-82, 2003.

North, Douglas, W.: Institutions, Institutional Change and Economic Performance, Cambridge University Press, 1990.

Parry, M. L., Canziani, O. F., Palutikof, J. P., van der Linden, P. J., and Hanson, C. E.: Climate Change 2007: Impacts, Adaption and Vulnerability. Contribution of Working Group II to the Fourth Assessment Report of the Intergovernmental Panel on Climate Change (IPCC), Cambridge University Press, New York, 2007.

Pelling, M.: The Political Ecology of Flood Hazard in Urban Guyana, Geoforum, 30, 249-261, 1999.

Raddatz, C.: Are External Shocks Responsible for the Instability of Output in Low-Income Countries?, World Bank Policy Research Working Paper 3680, World Bank, 2005.

Raschky, P. A.: Estimating the Effects of Risk Transfer Mechanisms against Floods in Europe and USA: A Dynamic Panel Approch., Mimeo, Working Papers in Economics and Statistics No. 200705, University of Innsbruck, 2007.

Raschky, P. A. and Weck-Hannemann, H.: Charity Hazard - A Real Hazard to Natural Disaster Insurance?, Envrionmental Hazards, 7, 321-329, 2007.

Rasmussen, T. N.: Macroeconomic Implications of Natural Disasters in the Caribean, IMF Working Paper 04/224, International Monetary Fund, 2004. 
Schwarze, R. and Wagner, G. G.: In the Aftermath of Dresden: New Directions in German Flood Insurance, The Geneva Papers on Risk and Insurance, 29, 164-168, 2004.

Skidmore, M.: Risk, Natural Disasters, and Household Savings in a Life Cycle Model, Japan and the World Economy, 13, 15-34, 2001.

Skidmore, M. and Toya, H.: Do Natural Disasters Promote Longrun Growth?, Economic Inquiry, 40, 664-687, 2002.

Skidmore, M. and Toya, H.: Economic Development and the Impacts of Natural Disasters, Economics Letters, 94, 20-25, 2007.

Sobel, R. S. and Leeson, P. T.: Government's Response to Hurricane Katrina: A Public Choice Analysis, Public Choice, 127, 55-73, 2006.

Steininger, K. W. and Weck-Hannemann, H.: Global Environmental Change in Alpine Regions: Recognition, Impact, Adaption and Mitigation, New Horizons in Environmental Economics, Edward Elgar Publishing, 2002.
Tavares, J.: The Open Society Assesses its Enemies: Shocks, Disasters and Terrorist Attacks, Journal of Monetary Economics, 51, 1039-1070, 2004.

The PRS Group Inc.: International Country Risk Guide, Tech. rep., Political Risk Services and International Country Risk Guide (ICRG), 2006.

Varnes, D. J.: Landslide Hazard Zonation: A Review of Principles and Practice, UNESO, Paris, 1988.

Von Ungern-Sternberg, T.: Efficient Monopolies: The Limits of Competition in the European Property Insurance Market, Oxford University Press, 2004.

Weck-Hannemann, H.: Efficiency of Protective Measures, in: Risk 21 - Coping with Risks Due to Natural Hazards in the 21st Century, edited by Amman, W. J., Dannemann, S., and Vulliet, L., 147-154, Taylor \& Francis, 2005. 